ARTICLE

\title{
Photocathode functionalized with a molecular cobalt catalyst for selective carbon dioxide reduction in water
}

Palas Baran Pati ${ }^{1,5}$, Ruwen Wang 2,5 , Etienne Boutin ${ }^{2,5}$, Stéphane Diring ${ }^{1}$, Stéphane Jobic ${ }^{3}$, Nicolas Barreau (iD ${ }^{3 凶}$, Fabrice Odobel (1) ${ }^{1 凶} \&$ Marc Robert (10) $2,4 凶$

Artificial photosynthesis is a vibrant field of research aiming at converting abundant, low energy molecules such as water, nitrogen or carbon dioxide into fuels or useful chemicals by means of solar energy input. Photo-electrochemical reduction of carbon dioxide is an appealing strategy, aiming at reducing the greenhouse gas into valuable products such as carbon monoxide at low or without bias voltage. Yet, in such configuration, there is no catalytic system able to produce carbon monoxide selectively in aqueous media with high activity, and using earth-abundant molecular catalyst. Upon associating a p-type $\mathrm{Cu}(\mathrm{In}, \mathrm{Ga})$ $\mathrm{Se}_{2}$ semi-conductor with cobalt quaterpyridine complex, we herein report a photocathode complying with the aforementioned requirements. Pure carbon dioxide dissolved in aqueous solution ( $\mathrm{pH}$ 6.8) is converted to carbon monoxide under visible light illumination with partial current density above $3 \mathrm{~mA} \mathrm{~cm}^{-2}$ and $97 \%$ selectivity, showing good stability over time.

\footnotetext{
${ }^{1}$ Université de Nantes, CNRS, CEISAM UMR 6230, F-44000 Nantes, France. ${ }^{2}$ Université de Paris, Laboratoire d'Electrochimie Moléculaire, CNRS, F75006 Paris, France. ${ }^{3}$ Université de Nantes, CNRS, Institut des Matériaux Jean Rouxel, IMN, F-44000 Nantes, France. ${ }^{4}$ Institut Universitaire de France (IUF), F-75005 Paris, France. ${ }^{5}$ These authors contributed equally: Palas Baran Pati, Ruwen Wang, Etienne Boutin ${ }_{\text {email: nicolas.barreau@univ-nantes.fr; }}$ fabrice.odobel@univ-nantes.fr; robert@u-paris.fr
} 
A rtificial photosynthesis is an important research area, since it represents one of the long-term credible solutions to reduce our dependence toward fossil fuels, and to produce storable chemical fuels or raw materials for chemical industry with a low carbon footprint. Directly inspired from natural photosynthesis, which consists of transforming atmospheric $\mathrm{CO}_{2}$ into biomass with sunlight, solar-driven conversion of $\mathrm{CO}_{2}$ into $\mathrm{CO}$ is a key transformation for artificial photosynthesis. Indeed, $\mathrm{CO}$ is a strategic building block for chemical industry, since it can be transformed into any liquid carbon-based hydrocarbons by Fischer-Tropsch process or into methanol and acetic acid by Cativa-Monsanto process, for which the markets and the infrastructures are already in place. Namely, there are several strategies to achieve $\mathrm{CO}_{2}$ photoinduced reduction. Homogeneous photochemistry with molecular catalysis usually offers good selectivity, but catalyst reusability and coupling the reduction process with a useful and benign oxidation reaction remain a challenge although indispensable for practical applications $^{1-3}$. Heterogeneous catalysis at an electrode offers the opportunity to split oxidative and reductive processes into two different compartments through electrochemistry. An approach closely inspired by homogeneous photochemistry is to graft both photosensitizer (PS) and catalyst at an electrode, reproducing conditions of photochemistry at the interface, then replacing the sacrificial electron donor by an electrode. This strategy has been proven to be efficient in terms of selectivity and applied potential, but remains subject to low current density (typical photocurrent density being well below $\left.100 \mu \mathrm{A} / \mathrm{cm}^{2}\right)^{4-6}$, owing to dominant charge recombination, notably between the molecular photocatalytic system and the holes in the semiconductor (SC). Another approach, inspired by photovoltaic (PV) cells, consists of positioning the catalyst at the interface between a p-type SC electrode and the electrolyte. This strategy has been the object of interest in the $1980 \mathrm{~s}^{7-9}$ and has attracted renewed attention over the last 10 years, leading to stimulating results ${ }^{10-14}$. Studies in water are scarce, usually involving the use of precious metal complexes as catalysts ${ }^{11,15}$ and/or necessitating large overpotential ${ }^{8}$. More recently, photocathodes displaying a buried junction have emerged ${ }^{16-20}$. In this configuration, a narrowbandgap p-type SC, that is often subject to photocorrosion ${ }^{21}$, is protected by a wide-bandgap n-type SC in order to get longer lifetime and form a complete $\mathrm{p}-\mathrm{n}$ junction. This protecting layer, usually constituted of several wide-bandgap SCs, also offers an interesting platform for grafting catalyst. In early reports from Grätzel, Mayer et al., good current densities were obtained with high selectivity for CO (>80\%), but these studies were performed in organic solvent, with a precious Re complex catalyst (first in solution $^{16}$ and then grafted onto the electrode ${ }^{17}$ ), and they required rather negative potentials (ca. $-1.75 \mathrm{~V}$ vs. $\mathrm{Fc}^{+} / \mathrm{Fc}$ ). Recently, a hematite $\left(\mathrm{Fe}_{2} \mathrm{O}_{3}\right)$ photocathode co-doped with nitrogen and zinc has been reported ${ }^{18}$. The surface of the iron oxide was coated with a layer of $\mathrm{TiO}_{2}$ and a $\mathrm{Ru}$ complex was then electropolymerized on top. In aqueous electrolyte and under simulated sunlight, the system was able to achieve a selectivity of $63 \%$ for formate or $66 \%$ for CO, depending on the catalyst used. With one of these catalysts, total photocurrent density of $0.15 \mathrm{~mA} \mathrm{~cm}^{-2}\left(j_{\mathrm{HCOO}^{-}}=0.094 \mathrm{~mA} \mathrm{~cm}^{-2}, j_{\mathrm{CO}}=0.05 \mathrm{~mA} \mathrm{~cm}^{-2}\right)$ under an applied bias of $+0.1 \mathrm{~V}$ vs. RHE $(200 \mathrm{mV}$ underpotential) was maintained for several hours of operation. A junction made of $\mathrm{p}$ - and n-type silicon nanowires ( $\mathrm{p}-\mathrm{Si}$ and $\mathrm{n}-\mathrm{Si}$, respectively) and covered by $\mathrm{n}-\mathrm{GaN}$ was also reported and associated with a molecular assembly composed of a $\mathrm{Ru}$ tris-bipyridine dye and a $\mathrm{Ru}$ bipyridine complex acting respectively as a light harvester and a $\mathrm{CO}_{2}$ reduction catalyst ${ }^{19}$. In neutral aqueous medium and under sunlight irradiation, this multiple-absorber system generated formate with Faradaic efficiency (FE) in the range $35-65 \%$ and with a maximum partial photocurrent density for formate of $0.72 \mathrm{~mA} \mathrm{~cm}^{-2}$ at $-0.25 \mathrm{~V}$ vs. RHE. Remarkably, the current density was stable for more than $20 \mathrm{~h}$ of operation, but again precious metal complex was used, and the applied potential remains rather negative for a system containing two light absorbers assembled in series. Eventually, Reisner et al. developed a buried junction photocathode featuring an earth-abundant metal catalyst. A p-Si SC was covered with a film of $\mathrm{TiO}_{2}$ nanoparticles on which bis-terpyridine cobalt complex was anchored via phosphonic acid groups ${ }^{20}$. However, in water, partial photocurrent densities remained low $\left(j_{\mathrm{CO}}=\right.$ $0.018 \mathrm{~mA} \mathrm{~cm}^{-2}$ and $\left.j_{\mathrm{HCOO}}-=0.024 \mathrm{~mA} \mathrm{~cm}^{-2}\right)$ at $0 \mathrm{~V}$ vs. RHE in neutral medium $\left(0.1 \mathrm{M} \mathrm{KHCO}_{3}\right)$, with selectivities of 16 and $21 \%$ for CO and formate, respectively. In other words, no photocathode made of earth-abundant molecular catalyst is yet able to present concomitantly, a good selectively for $\mathrm{CO}$ or formate, a near-zero overpotential, and large current densities when working in aqueous solution.

Here, we report a photocathode based on $\mathrm{Cu}(\mathrm{In}, \mathrm{Ga}) \mathrm{Se}_{2}$ (CIGS) $\mathrm{SC}$ and cobalt quaterpyridine catalyst that complies with all of these requirements. This study is also the first report of CIGS SC as a constituent of a molecular-based photocathode for $\mathrm{CO}_{2}$ reduction in water. Our step-by-step photocathode elaboration starting from electrochemical (EC) configuration, then PV + EC, and eventually photo-EC (PEC) configuration is detailed.

\section{Results}

(Photo)-electrode preparation and characterization. Cobalt quaterpyridine, aside from including an earth-abundant metal, is one of the most efficient $\mathrm{CO}_{2}$-to-CO reduction molecular catalyst, operating at overpotential as low as ca. $350 \mathrm{mV}$ in aqueous neutral conditions ${ }^{22}$. Association with a buried $\mathrm{p}-\mathrm{n}$ junction able to produce this range of photovoltage should thus allow to work near or under thermodynamic potential for $\mathrm{CO}_{2}$-to-CO conversion. Here, we prepared the cobalt complex with planar tetradentate ligand $2,2^{\prime}: 6^{\prime}, 2^{\prime \prime}: 6^{\prime \prime}, 2^{\prime \prime \prime}$-quaterpyridine (Co-qPyH, Fig. 1), whose parent compound is known to be an efficient EC but also photochemical $\mathrm{CO}_{2}$ reduction catalyst, able to operate in aqueous media with good activity and stability $22-25$. The catalyst is substituted with two phosphonic acid groups allowing for grafting on the surface of a metal oxide layer. Phosphonic acid proved to be among the most stable binding groups on metal oxide surfaces, provided $\mathrm{pH}$ range $(<7)$ is respected ${ }^{26-28}$.

Co-qPyH was synthesized by the route described in the "Methods" section and was carefully characterized (Supplementary Fig. 1). This complex exhibits only a weak absorbance in the visible spectrum and therefore leaves the electrode almost transparent to most of the incoming solar irradiation. Flat $\mathrm{TiO}_{2}$ $\left(\mathbf{f}-\mathbf{T i O}_{2}\right)$ and mesoporous $\left.\mathrm{TiO}_{2}(\mathbf{m}-\mathbf{T i O})_{2}\right)$ were used as both grafting surface and protecting top layer. After deposition of this oxide on FTO, Mott-Schottky analysis revealed a donor density $\left(N_{\mathrm{D}}\right)$ of $6.3 \times 10^{20} \mathrm{~cm}^{-3}$ in the conduction band (Supplementary Fig. 2), suitable for an electron-transporting layer. Ultraviolet-visible (UV-vis) absorption spectra were recorded on $\mathbf{m}$ - $\mathbf{T i O}_{2} \mid$ FTO surface before and after catalyst grafting upon a soaking step (Supplementary Fig. 3), which confirmed the modification of the semiconducting surface. Upon attenuated total reflectance-infrared spectroscopy (ATR-IR) analysis, resemblance in fingerprint regions between Co-qPyH powder and $\mathbf{C o - q P y H}$-loaded $\mathbf{~ m}-\mathbf{T i O}_{2}$ electrode (Co$\left.\mathbf{q P y H} \mid \mathbf{m}-\mathbf{T i O}_{2}\right)$ further suggests that the catalyst is grafted on the surface (Fig. 2). The bands at $\sim 1390, \sim 1490, \sim 1546$, and $\sim 1601 \mathrm{~cm}^{-1}$ assigned for aromatic ring stretching vibration corroborate structural preservation of the catalyst upon immobilization. 
a

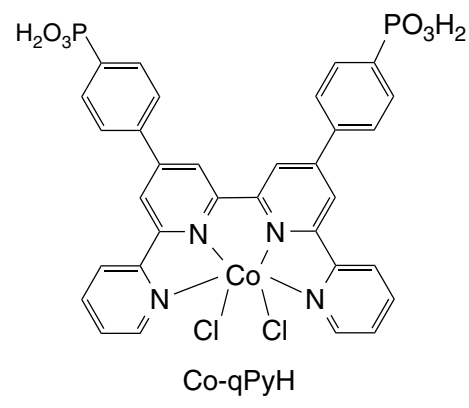

b

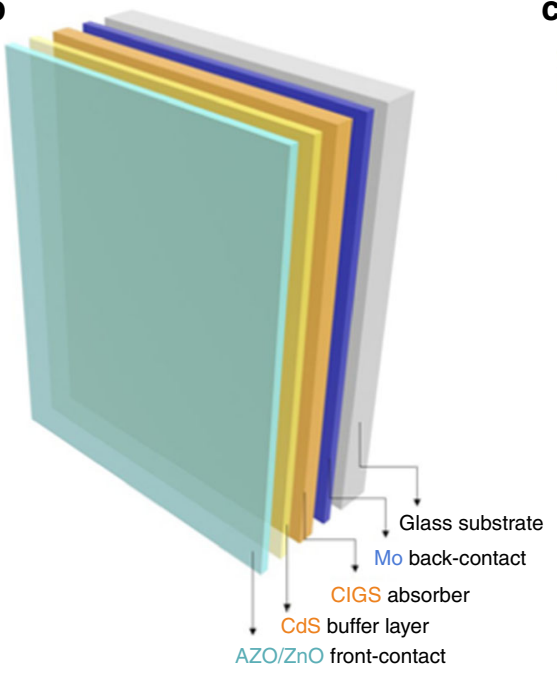

C

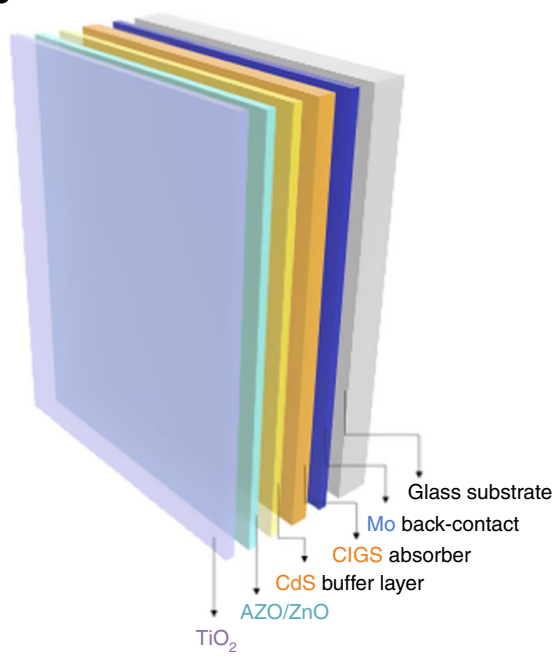

Fig. 1 Electrode components. Structure of the Co-qPyH molecular catalyst bearing phosphonic acid functions (a). Schematic view of the CIGS-based layered material used in PV conditions (b) and in PEC conditions (c). Additional layers to CIGS are molybdenum (Mo), cadmium sulfide (CdS), aluminumdoped zinc oxide $(\mathrm{AZO} / \mathrm{ZnO})$, and titanium dioxide $\left(\mathrm{TiO}_{2}\right)$.

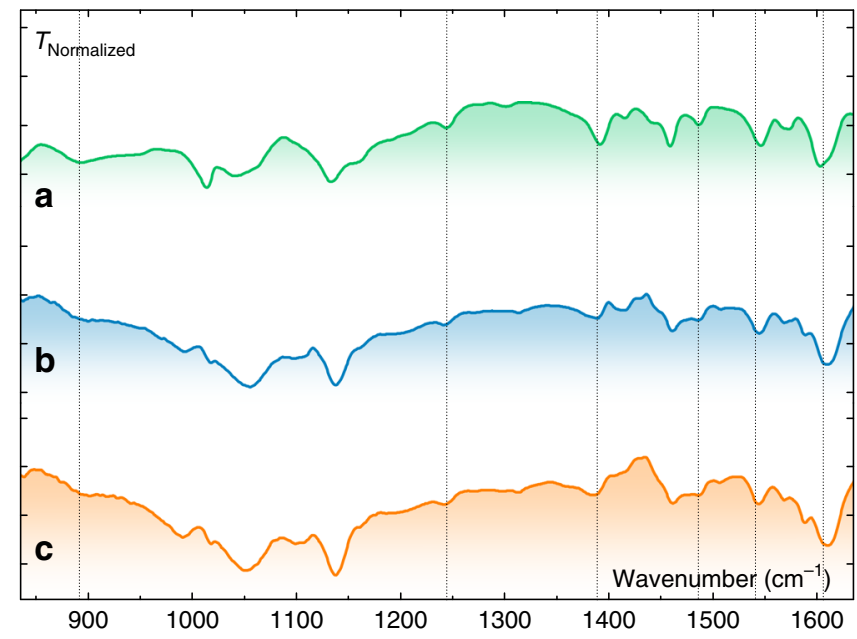

Fig. 2 ATR-IR spectrum of Co-qPyH complex catalyst. From a powder (a), deposited on $\mathbf{m}-\mathbf{T i O}_{\mathbf{2}}$ before (b) and after (c) $1 \mathrm{~h}$ of electrolysis performed in $0.1 \mathrm{M} \mathrm{KHCO}_{3}$ electrolyte saturated with $\mathrm{CO}_{2}(\mathrm{pH} \mathrm{6.8)}$ at $-0.56 \mathrm{~V}$ vs. RHE.

On the other hand, the disappearance of a band near $893 \mathrm{~cm}^{-1}$ (P-OH) of Co-qPyH after surface attachment along with the presence of the band at $1243 \mathrm{~cm}^{-1}(\mathrm{P}=\mathrm{O}$ stretching) suggests typical bidentate binding of phosphonate on $\mathrm{TiO}_{2}$ surface ${ }^{26-28}$, with $\mathrm{P}=\mathrm{O}$ functional group not involved in the linkage. XPS analyses (Fig. 3, blue) show a signal for $\mathrm{P}_{2 \mathrm{p}}$ that is characteristic of phosphate $(132.5 \mathrm{eV})^{17,20}$, a $\mathrm{N}_{1 \mathrm{~s}}$ signal characteristic of a pyridinic nitrogen complexing a cobalt atom in a quaterpyridine ligand $(399.5 \mathrm{eV})^{22}$, and that of $\mathrm{Co}_{2 \mathrm{p}}$ indicative of a $\mathrm{Co}^{2+}$ oxidation state (main peak at $780 \mathrm{eV}$, secondary peak at $796 \mathrm{eV}$, and two shoulders at 785 and $803 \mathrm{eV}$, respectively), confirming the presence of the catalyst. Complementary EDX-mapping experiment (Supplementary Fig. 4) shows a consistent atomic ratio of 2:1 between phosphate and cobalt, definitively proving the presence of the catalyst and confirming its intactness after grafting. Mapping of Co element revealed the absence of cobalt aggregate, suggesting a homogeneous distribution of the catalyst on the overall surface. Inductively coupled plasma optical emission spectrometry (ICP-OES) measurements after catalyst dissolution (acidic treatment), indicate catalyst loading of $29 \pm$ $4 \mathrm{nmol} \mathrm{cm}{ }^{-2}$ on $\mathbf{m}-\mathbf{T i O}_{2}$ film and $3 \pm 1 \mathrm{nmol} \mathrm{cm}{ }^{-2}$ in $\mathbf{f}-\mathbf{T i O}_{2}$ film (see "Methods" for details). This concentration is about one-third of previously reported data $\left(85 \mathrm{nmol} \mathrm{cm}{ }^{-2}\right.$ for a Re complex with a similar anchoring group on mesoporous $\left.\mathrm{TiO}_{2}\right)^{17}$, leaving room for improvement.

EC reduction of $\mathrm{CO}_{2}$. The catalytic activity of $\mathrm{Co}-\mathbf{q P y H} \mid \mathbf{m}-\mathrm{TiO}_{2}$ electrode was first explored by cyclic voltammetry (CV). In $0.1 \mathrm{M}$ $\mathrm{KHCO}_{3}$ aqueous solution saturated with $\mathrm{CO}_{2}(\mathrm{pH}=6.8)$, catalytic current was observed with an onset potential at ca. $-0.3 \mathrm{~V}$ vs. RHE (Fig. 4a). Long-term electrolysis at $-0.51 \mathrm{~V}$ vs. RHE (2 h) led to an average catalytic current of $1.2 \mathrm{~mA} \mathrm{~cm}^{-2}$ (Supplementary Fig. 5), and gas chromatography (GC) analysis of the products indicated formation of CO with $80 \%$ selectivity and $63 \% \mathrm{FE}$ along with $\mathrm{H}_{2}$ as the by-product (entry 1, Table 1). The current density, after reaching a steady-state value in the first $15 \mathrm{~min}$, remained stable for $2 \mathrm{~h}$ without significant change. Electrolysis performed under argon in the same conditions of $\mathrm{pH}(0.1 \mathrm{M}$ phosphate buffer) and potential did not yield any CO (entry 2, Table 1). An ATR analysis of the electrode before and after $1 \mathrm{~h}$ of electrolysis in $0.1 \mathrm{M} \mathrm{KHCO}_{3}$ saturated with $\mathrm{CO}_{2}(\mathrm{pH}$ 6.8) at $-0.56 \mathrm{~V}$ vs. RHE (Fig. 2) showed good stability of the catalyst and the grafting since characteristic signals remained almost unchanged. XPS analysis of the electrode before and after a longer $(2 \mathrm{~h})$ electrolysis in $0.1 \mathrm{M} \mathrm{KHCO}_{3}$ saturated with $\mathrm{CO}_{2}(\mathrm{pH}$ 6.8) at $-0.51 \mathrm{~V}$ vs. RHE (Fig. 3) confirmed such stability even if the intensity of the signal was slightly dampened. This signalintensity decrease is pointing toward slow catalyst desorption rather than catalyst decomposition. This is most likely due to the fact that working $\mathrm{pH}$ is close to the upper limit for phosphonate group stability ${ }^{27}$. Nevertheless, the above results indicate that the cobalt quaterpyridine complex kept its catalytic activity after functionalization with phosphonic acid and immobilization at a quasi-transparent $\mathbf{m}-\mathrm{TiO}_{2}$ electrode. Compared with the immobilization on carbon nanotube in similar conditions ${ }^{22}$, the current density measured in water is lower, but the $\mathrm{TiO}_{2}$ inorganic support presents the advantage of being transparent toward a large portion of the sunlight and therefore compatible as a support layer on photoelectrode surfaces. 

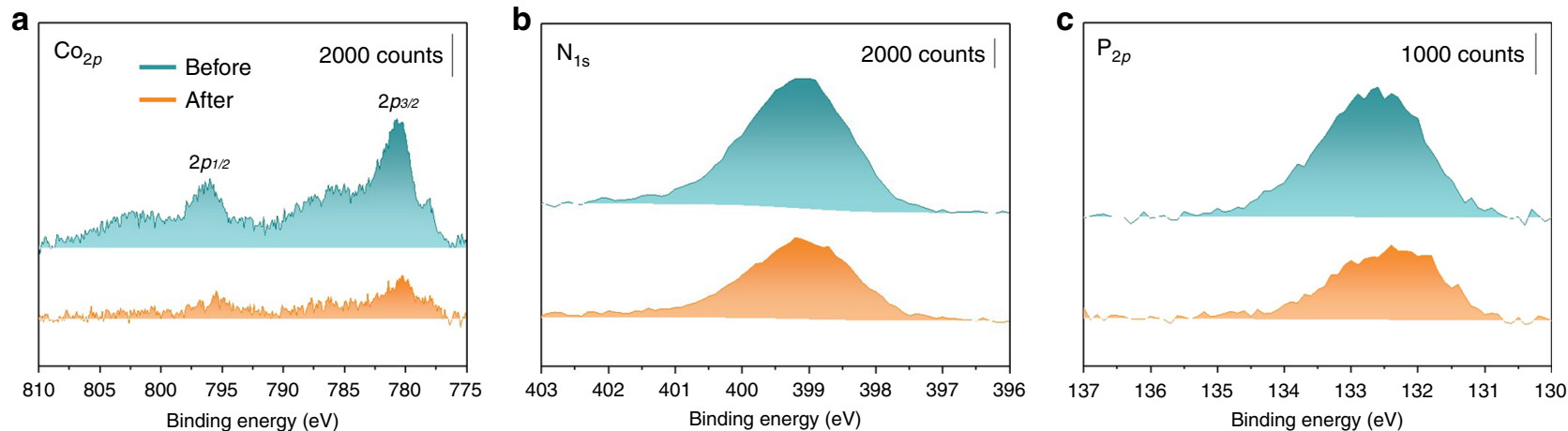

Fig. 3 XPS analysis of the $\mathbf{C o - q P y H} \mid \mathbf{m}-\mathbf{T i O}_{\mathbf{2}}$ electrode. Before (blue trace) and after (orange trace) $2 \mathrm{~h}$ of electrolysis at $-0.51 \mathrm{~V}$ vs. $\mathrm{RHE}$ in $0.1 \mathrm{M} \mathrm{KHCO}$ electrolyte saturated with $\mathrm{CO}_{2}(\mathrm{pH}=6.8)$. Data show binding energies for $\mathrm{Co}_{2 \mathrm{p}}(\mathbf{a}), \mathrm{N}_{1 \mathrm{~s}}(\mathbf{b})$, and $\mathrm{P}_{2 \mathrm{p}}(\mathbf{c})$.
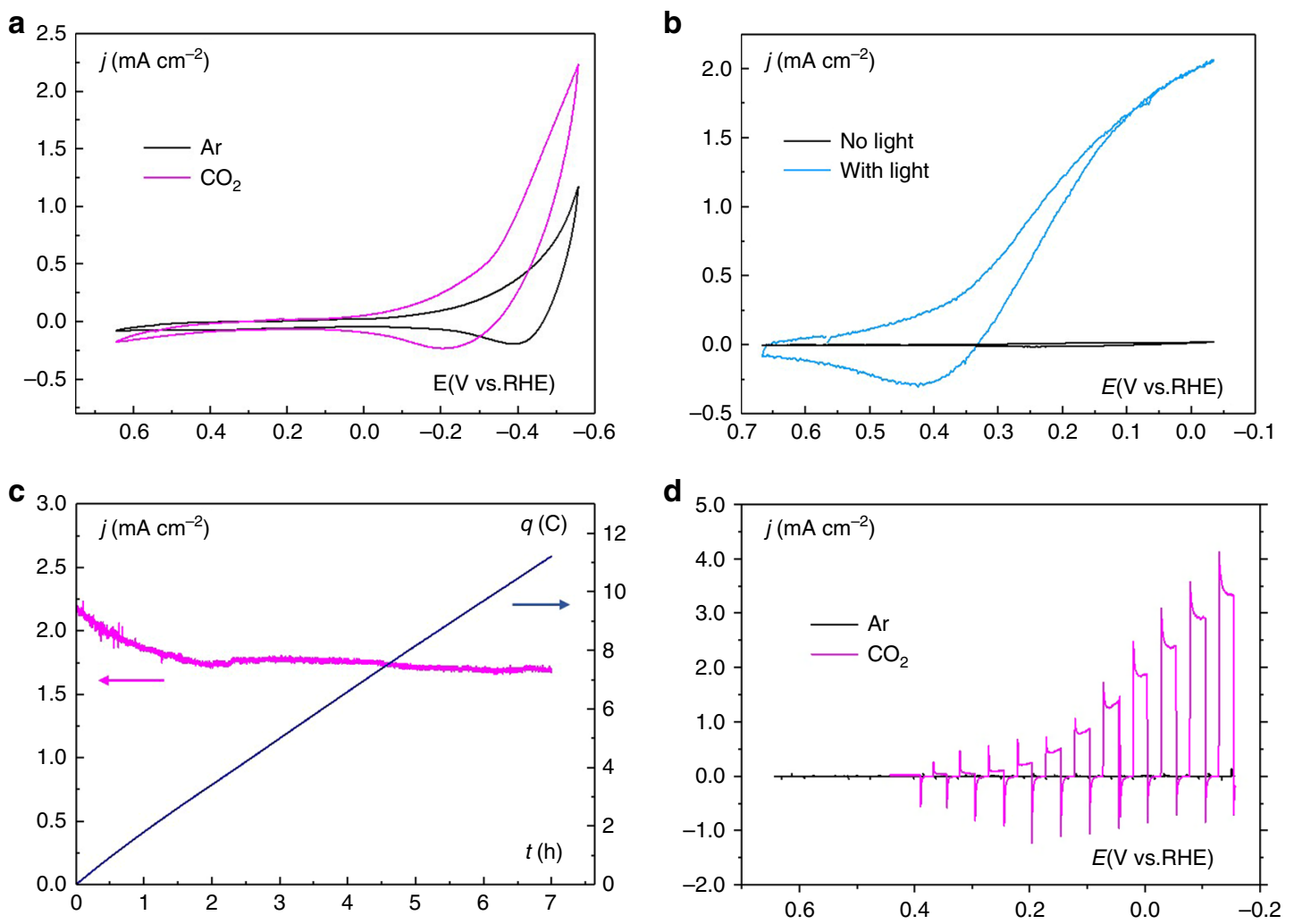

Fig. 4 Electrochemical and photoelectrochemical data in various configurations. a CV in EC conditions at a $\mathbf{C o -} \mathbf{q} \mathbf{P y H} \mid \mathbf{m}-\mathbf{T i O} \mathbf{O}_{\mathbf{2}}$ electrode in $0.1 \mathrm{M} \mathrm{KHCO}$, saturated with argon (black) or $\mathrm{CO}_{2}$ (magenta). Scan rate was $20 \mathrm{mV} \mathrm{s}^{-1}$. b CV in PV + EC conditions at a $\mathbf{C o - q P y H} / \mathbf{m}-\mathbf{T i O} \mathbf{O}_{\mathbf{2}}$ electrode in $0.1 \mathrm{M} \mathrm{KHCO}$ saturated with $\mathrm{CO}_{2}$, connected to CIGS solar cells without (black) and with light illumination (blue). Scan rate was 20 mV s s. $^{-1} \mathbf{c}$ Long-term electrolysis in $\mathrm{PV}+\mathrm{EC}$ conditions at a $\mathbf{C o}-\mathbf{q} \mathbf{P y H} \mid \mathbf{m}-\mathbf{T i O}_{\mathbf{2}}$ electrode in $0.5 \mathrm{M} \mathrm{KHCO}_{3}$ saturated with $\mathrm{CO}_{2}(\mathrm{pH} 7.2)$, connected to an external irradiated CIGS solar cells

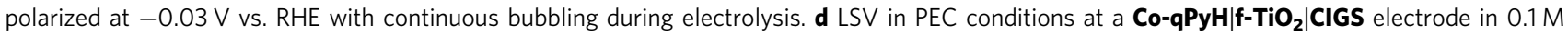
phosphate buffer saturated with argon $\left(\mathrm{pH} 6.8\right.$, black) or $0.1 \mathrm{M} \mathrm{KHCO}_{3}$ electrolyte saturated with $\mathrm{CO}_{2}(\mathrm{pH} 6.8$, magenta) under chopped light irradiation. Scan rate was $5 \mathrm{mV} \mathrm{s}^{-1}$.

Hybrid PV-EC reduction of $\mathrm{CO}_{2}$. Considering the good performances of $\mathbf{C o}-\mathbf{q P y H} \mid \mathbf{m}-\mathbf{T i O}_{2}$ electrode in EC conditions, we then used this hybrid material as top layer in association with SCs. Copper chalcogenide SCs, such as p-type CIGS, are appealing materials for the development of $\mathrm{CO}_{2}$ reduction photocathodes, but surprisingly they have not been used yet for such application although successful utilization of CIGS for hydrogen evolution has been reported ${ }^{29-31}$. CIGS materials present the advantage to highly absorb in the visible range, their bandgaps are easily tunable through variation of the composition (In/Ga ratio), and they can be manufactured at low cost with current industrial processes $^{32}$. Also note that high-performance and affordable
CIGS-based PV cells have led to high power conversion efficiencies (above 23\%) while they also have reached the commercial stage $^{33}$. We prepared a $\mathrm{p}-\mathrm{n}$ junction made of this SC and a $\mathrm{n}-\mathrm{CdS}$ layer, and the material was further protected by $\mathrm{ZnO}$ and $\mathrm{ZnO}: \mathrm{Al}$ (AZO) layers. Hereafter, CIGS refers specifically to $\mathrm{Cu}$ $\left(\mathrm{In}_{0.1} \mathrm{Ga}_{0.9} \mathrm{Se}_{2}\right)$ composition and a scanning electron microscopy image was obtained (SEM, Supplementary Fig. 6). $J-V$ curve on this CIGS cell (Supplementary Fig. 7) showed a maximum lightto-electricity conversion at $580-\mathrm{mV}$ photovoltage. At this photovoltage, the CIGS cell is delivering ca. $15 \mathrm{~mA} \mathrm{~cm}^{-2}$ current density, compatible with previously reported aqueous EC reduction of $\mathrm{CO}_{2}$ to $\mathrm{CO}$ catalyzed by $\mathrm{Co}$ quaterpyridine complex 


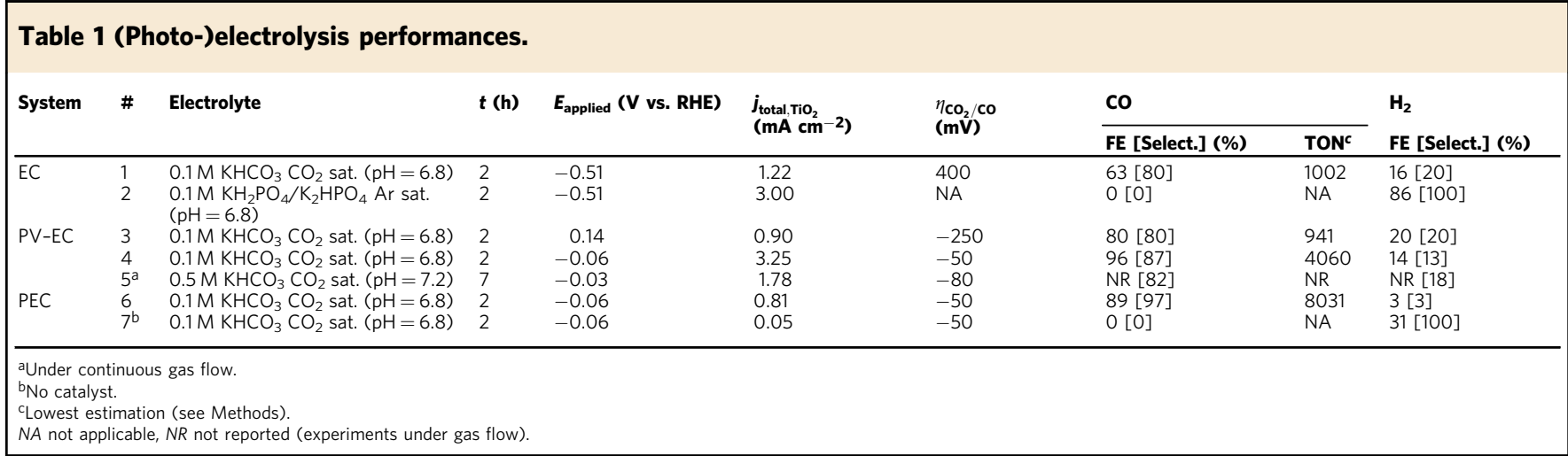

a

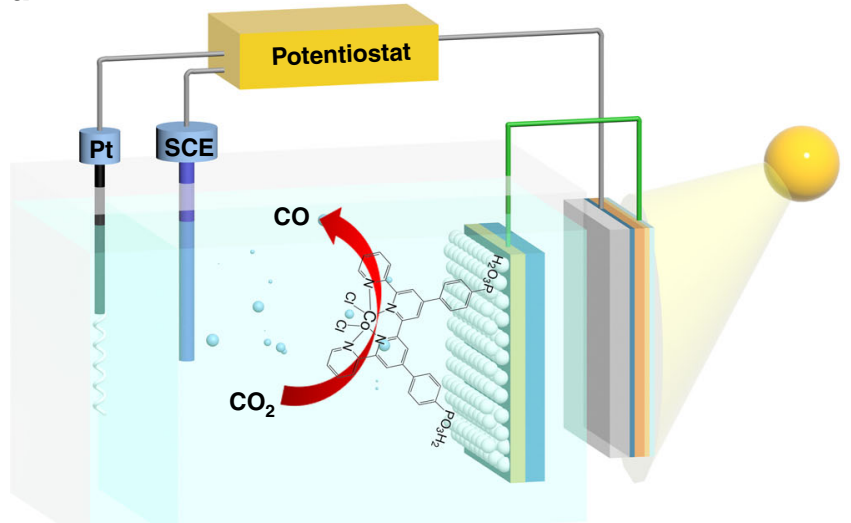

b

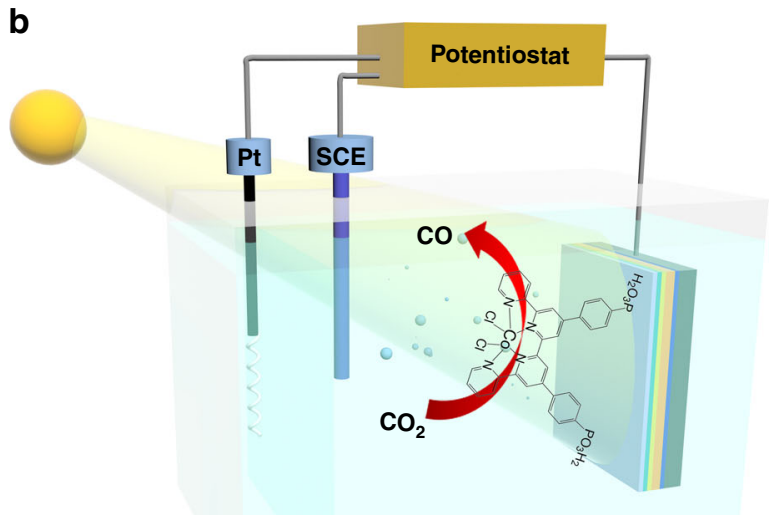

Fig. 5 Illustrative schemes of the photo-assisted cell systems investigated in this study. PV-EC system (a) and PEC system (b).

immobilized on carbon nanotubes $(E=-0.51 \mathrm{~V} \text { vs. RHE })^{22}$. Even though $\mathbf{C o - q P y H} \mid \mathbf{m}-\mathrm{TiO}_{2}$ electrodes were not yet optimized to reach this range of current densities in EC conditions, we decided to work in this photovoltage range. The working potential under illumination of the cathode was thus set at -0.06 $\mathrm{V}$ vs. RHE. Two successive strategies were devised, as illustrated in Figs. 5a, b. First, an external CIGS PV cell (ZnO:Al|ZnO $|\mathbf{C d S}|$ CIGS|Mo material, see "Methods" for details) was coupled with the above Co-qPyH $\mid \mathbf{m}-\mathbf{T i O}_{2}$ electrode (Fig. 5a). Second, a fully integrated $\mathrm{PEC}$ was set upon depositing $\mathbf{f}-\mathbf{T i O} \mathbf{O}_{2}$ layer directly on top of the $\mathrm{ZnO}: \mathrm{Al} / \mathrm{ZnO} / \mathrm{CdS} / \mathrm{CIGS} / \mathrm{Mo}$ stack and further functionalized with Co-qPyH (Fig. 5b).

Coupling a PV cell to an electrolyzer $(\mathrm{PV}+\mathrm{EC})$ is a valuable approach to utilize the photogenerated charges in the solar cell and activate a substrate in solution. In this configuration, the photoactive material is not in direct contact with the solution, which partly solves stability issues. The $\mathbf{C o}-\mathbf{q P y H} \mid \mathbf{m}-\mathbf{T i O}_{2}$ electrode was connected to CIGS solar cells (ZnO:Al/ZnO/CdS/ CIGS/Mo), and the photocurrent was measured by recording a linear scan voltammetry (LSV) under chopped light (Supplementary Fig. 8a) showing a photocurrent up to $1 \mathrm{~mA} \mathrm{~cm}^{-2}$. Electrolysis experiments were then carried out in a $0.1 \mathrm{M} \mathrm{KHCO}_{3}$ solution saturated with $\mathrm{CO}_{2}$ (at $\mathrm{pH}$ 6.8) for $2 \mathrm{~h}$. Average current density of 0.90 and $3.25 \mathrm{~mA} \mathrm{~cm}^{-2}$ reported per geometric surface of $\mathbf{m}-\mathbf{T i O}_{2}$ was obtained, under applying a bias potential of 0.14 and $-0.06 \mathrm{~V}$ vs. RHE, respectively (Supplementary Fig. 8b). Analysis of the reaction products indicates that the selectivity toward CO was $87 \%$ when the bias potential was -0.06 vs. RHE, which corresponds to a negative overpotential $\eta=-50 \mathrm{mV}$ (entries 3 and 4, Table 1). A longer-term, 7-h electrolysis was then performed in a $0.5 \mathrm{M}$ $\mathrm{KHCO}_{3}$ electrolyte under continuous flow of $\mathrm{CO}_{2}(\mathrm{pH} 7.2)$ at a potential of $-0.03 \mathrm{~V}$ vs. $\mathrm{RHE}\left(\eta=-80 \mathrm{mV}\right.$ for $\mathrm{CO}_{2} / \mathrm{CO}$ reaction) (Fig. 4c). The average current density was $1.78 \mathrm{~mA} \mathrm{~cm}^{-2}$ and the selectivity for CO production was maintained between 82 and $85 \%$ during the whole course of the experiment (entry 5, Table 1).

PEC reduction of $\mathrm{CO}_{2}$. In a second approach, and as explained above, an integrated PEC with the Co-qPyH catalyst directly immobilized on a CIGS-based photocathode was developed (Fig. 5b). To do so, the surface of the complete $\mathbf{Z n O}: \mathbf{A l} / \mathbf{Z n O} /$ CdS/CIGS/Mo electrode was first protected by a dense layer of $\mathrm{TiO}_{2}$ (5 to $10 \mathrm{~nm}$ thick, $\mathbf{f}-\mathbf{T i O}_{2}$ ) deposited by sputtering, and the catalyst was loaded by chemisorption using the same conditions as those used for $\mathbf{m}-\mathbf{T i O}_{2}$ film (Co-qPyH $\left|\mathbf{f}-\mathbf{T i O}_{2}\right| \mathbf{C I G S}$ ). As expected, a lower catalyst loading was measured by ICP-OES, $3 \pm$ $1 \mathrm{nmol} / \mathrm{cm}^{2}$, corresponding to a decrease by a factor 10 as compared with $\mathbf{m}-\mathbf{T i O}_{2}$ film. Linear sweep voltammetry with chopped illumination in $0.1 \mathrm{M} \mathrm{KHCO}_{3}$ aqueous solution (Fig. $4 \mathrm{~d}$ ) revealed a photoresponse with an onset potential of $0.2 \mathrm{~V}$ vs. RHE, while a control experiment under Ar showed negligible photocurrent modulation in the same $\mathrm{pH}$ conditions. When long-term photoelectrocatalysis experiment was carried out at a bias potential of $-0.06 \mathrm{~V}$ vs. RHE (entry 6 , Table 1 ), an average current density of $0.8 \mathrm{~mA} \mathrm{~cm}^{-2}$ was recorded. It showed only a slight decay along the $2 \mathrm{~h}$ electrolysis (Supplementary Fig. 9). Selectivity of $97 \%$ for $\mathrm{CO}$ was obtained with only $3 \%$ of $\mathrm{H}_{2}$ as the by-product. The decrease in photocurrent density during the photoelectrolysis can 

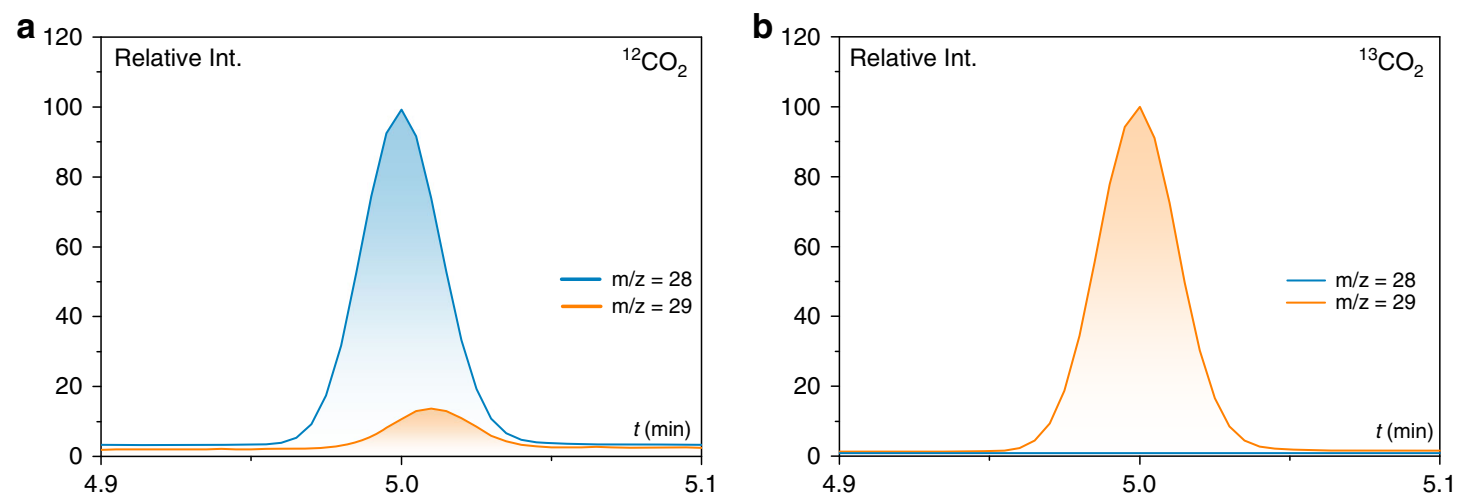

Fig. 6 GC/MS chromatograms at the retention time of carbon monoxide. Specific traces of $m / z=28$ value (blue) and $m / z=29$ value (orange) after $2 \mathrm{~h}$ of electrolysis at illuminated $\mathbf{C o - q P y H}\left|\mathbf{f}-\mathbf{T i O}_{\mathbf{2}}\right| \mathbf{C I G S}$ ( $E_{\text {bias }}=-0.06 \mathrm{~V}$ vs. $\mathrm{RHE}$ ), in $0.1 \mathrm{M} \mathrm{KHCO}$ electrolyte saturated with ${ }^{12} \mathrm{CO}_{2}(\mathbf{a})$ and ${ }^{13} \mathrm{CO}_{2}(\mathbf{b})$.

be explained by catalyst leaching from the electrode, and/or instability of the composing layers, particularly if the AZO underlayer gets into contact with the aqueous environment. Nonetheless, it is remarkable that such a high selectivity for $\mathrm{CO}$ production could be obtained for several hours with this fully integrated device, at a negative overpotential relatively to $E^{0^{\prime}}$ $\left(\mathrm{CO}_{2} / \mathrm{CO}\right)$. A turnover number for $\mathrm{CO}$ production over 8000 was calculated (entry 6, Table 1). It corresponds to a mean turnover frequency (TOF) of $1.1 \mathrm{~s}^{-1}$. Note that TON and TOF values are underestimated since they were calculated from the total surface concentration of the catalyst and not from the electroactive fraction of it. A blank experiment was conducted without catalyst grafted on $\mathrm{TiO}_{2}$ (entry 7, Table 1) and gave no CO along with low current density. Electrolysis experiment was also repeated with ${ }^{13} \mathrm{CO}_{2}$, and analysis of products via GC/MS compared with experiments under ${ }^{12} \mathrm{CO}_{2}$ confirmed that $\mathrm{CO}$ originated from $\mathrm{CO}_{2}$ (Fig. 6).

\section{Discussion}

To the best of our knowledge, this work represents the first demonstration where a CIGS electrode has been successfully used for $\mathrm{CO}_{2}$ catalytic reduction. When combined with Co-qPyH molecular catalyst grafted on a titanium dioxide upper protective layer, good selectivity, activity, and negative overpotential were simultaneously obtained under visible-light illumination in neutral aqueous solution. It resulted in significant improved performances when compared with previously reported molecular hybrid systems, even those including noble metals (see in particular entries 1, 5, and 6 in Supplementary Table 1). In that latter case, for example, a maximum photocurrent density for $\mathrm{CO}$ of 45 $\mu \mathrm{Acm}^{-2}$ at $110 \mathrm{mV}$ overpotential was obtained with a $\mathrm{Ru}$ complex grafted onto a hematite photocathode ${ }^{18}$, more than one order of magnitude less than the $\mathbf{C o - q P y H}\left|\mathbf{f}-\mathbf{T i O}_{2}\right|$ CIGS photocathode. Notably, our study led to the first PEC device demonstrating photoelectrocatalytic activity in pure aqueous medium with $97 \%$ of selectivity for $\mathrm{CO}_{2}$ reduction to $\mathrm{CO}$. It paves the way to the development of better-performing photocathode PECs for $\mathrm{CO}_{2}$ reduction. Indeed, the system may be significantly improved with a higher catalyst loading with strategy such as nanostructuration of the upper oxide layer. Eventually, it could also end up in fully unassisted solar-driven fuel production when paired with an appropriate photoanodic reaction.

\section{Methods}

Catalyst synthesis. (1E,5E)-1,6-bis(4-bromophenyl)hexa-1,5-diene-3,4-dione (1) was synthesized as previously reported in literature and illustrated in Fig. $7^{34}$. To a vigorously stirred solution of 4 -bromobenzaldehyde $(11.1 \mathrm{~g}, 6 \mathrm{mmol})$ and piperidine $(0.6 \mathrm{ml}, 0.6 \mathrm{mmol})$ in $\mathrm{MeOH}$, a solution of 2,3-butadione $(2.58 \mathrm{~g}, 3 \mathrm{mmol})$ was added dropwise using a dropping funnel over $10 \mathrm{~min}$. The reaction mixture was heated to reflux for overnight. The solution was cooled in an ice bath, and the obtained orange precipitate was filtered and washed with diethyl ether. The orange compound was dried under vacuum to yield $2.71 \mathrm{~g}$ of compound 1 . This compound 1 was used directly for the next reaction without any further purification.

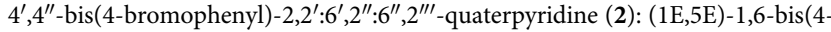
bromophenyl)hexa-1,5-diene-3,4-dione (1) $(420 \mathrm{mg}, 1.0 \mathrm{mmol})$ was added to a solution of the Kröhnke reagent N-[2-(2-pyridyl)-2-oxethyl]pyridinium iodide $(652 \mathrm{mg}, 3.26 \mathrm{mmol})$ and anhydrous ammonium acetate ( $8 \mathrm{~g}$, excess) in absolute ethanol $(40 \mathrm{ml})$ and the mixture heated under reflux for $24 \mathrm{~h}$. After cooling, the precipitate was filtered and washed with diethyl ether. Compound $\mathbf{2}$ is insoluble in common organic solvents. About $140 \mathrm{mg}$ of compound 2 was obtained as off-white powder with $23 \%$ yield. ${ }^{1} \mathrm{H}$ NMR characterization is shown in Supplementary Fig. $10\left(\mathrm{ppm}, 300 \mathrm{MHz}, 298 \mathrm{~K}, \mathrm{CDCl}_{3}\right) \delta 8.88(\mathrm{~d}, J=1.8 \mathrm{~Hz}, 2 \mathrm{H}), 8.75(\mathrm{~m}, 2 \mathrm{H})$, $8.74(\mathrm{~d}, J=1.8 \mathrm{~Hz}, 2 \mathrm{H}), 8.68(\mathrm{dt}, J=4.8,1.2 \mathrm{~Hz}, 2 \mathrm{H}), 7.92(\mathrm{td}, J=8.1,1.8 \mathrm{~Hz}, 2 \mathrm{H})$, $7.79(\mathrm{~d}, J=8.7 \mathrm{~Hz}, 4 \mathrm{H}), 7.68(\mathrm{~d}, J=8.7 \mathrm{~Hz}, 4 \mathrm{H})$, and $7.38(\mathrm{dt}, J=4.8,1.2 \mathrm{~Hz}, 2 \mathrm{H})$; HRMS $m / z$ calcd for $\mathrm{C}_{32} \mathrm{H}_{21} \mathrm{Br}_{2} \mathrm{~N}_{4}[\mathrm{M}+\mathrm{H}]^{+} 619.0133$, found 619.0137.

Tetraethyl $\left(\left[2,2^{\prime}: 6^{\prime}, 2^{\prime \prime}: 6^{\prime \prime}, 2^{\prime \prime \prime}\right.\right.$-quaterpyridine $]-4^{\prime}, 4^{\prime \prime}$-diylbis $(4,1$-phenylene) $)$ bis (phosphonate) (3) was formed via Hirao cross-coupling reaction: Compound 2 (100 mg, $0.16 \mathrm{mmol}), \mathrm{Pd}\left(\mathrm{PPh}_{3}\right)_{4}(17 \mathrm{mg}, 0.015 \mathrm{mmol})$, and $\mathrm{Cs}_{2} \mathrm{CO}_{3}(114 \mathrm{mg}, 0.35$ $\mathrm{mmol}$ ) were combined in anhydrous THF $(4 \mathrm{~mL})$ in a $10-\mathrm{mL}$ microwave vial equipped with a stirrer bar under argon. Diethylphosphite $(107 \mathrm{mg}, 0.78 \mathrm{mmol})$ was added by a syringe before the vial and purged with Ar for another $10 \mathrm{~min}$. The vial was sealed and the reaction mixture heated to $110^{\circ} \mathrm{C}$ for $2.5 \mathrm{~h}$. The reaction mixture was filtered to give a yellow solution, and then the solvent was evaporated under reduced pressure. The resulting brown residue was dissolved in $\mathrm{CH}_{2} \mathrm{Cl}_{2}$ $(20 \mathrm{~mL})$ and stirred with decolorizing charcoal for $30 \mathrm{~min}$ and then filtered over celite prior to removal of the solvent under reduced pressure to produce an oily bright-yellow residue. The residue was dissolved in acetone $(5 \mathrm{~mL})$ and filtered through a short silica plug eluting with acetone $(25 \mathrm{~mL})$ to give a pale-yellow solution. The solvent volume was reduced to $\approx 5 \mathrm{~mL}$ of cold pentane that was added, until compound $\mathbf{3}$ precipitated out from the solution. Compound $\mathbf{3}$ was isolated as a white powder (108 $\mathrm{mg}, 92 \%) .{ }^{1} \mathrm{H}$ NMR characterization is shown in Supplementary Fig. 11 (ppm, $\left.400 \mathrm{MHz}, 298 \mathrm{~K}, \mathrm{CDCl}_{3}\right) \delta 8.95(\mathrm{~d}, J=1.6 \mathrm{~Hz}, 2 \mathrm{H})$, $8.80(J=1.6 \mathrm{~Hz}, 2 \mathrm{H}), 8.75(\mathrm{~m}, 2 \mathrm{H}), 8.70(\mathrm{dt}, J=8.0,0.8 \mathrm{~Hz}, 2 \mathrm{H}), 8.01-8.03$ $(\mathrm{m}, 8 \mathrm{H}), 7.93(\mathrm{td}, J=7.6,1.6 \mathrm{~Hz}, 2 \mathrm{H}), 7.38(\mathrm{dt}, J=6.0,1.2 \mathrm{~Hz}, 2 \mathrm{H}), 4.13-4.26$ $(\mathrm{m}, 8 \mathrm{H})$, and $1.38(\mathrm{t}, J=6.8 \mathrm{~Hz}, 12 \mathrm{H}) ;{ }^{13} \mathrm{C}$ NMR characterization is shown in Supplementary Fig. 12 (ppm, $100 \mathrm{MHz}, 298 \mathrm{~K}, \mathrm{CDCl}_{3}$ ) $\delta 156.5,156.3,156.1,149.5$, $149.4,143.0,137.2,132.8,132.7,127.8,127.6,124.3,121.6,119.61,119.56,62.5$, $62.4,16.6,16.5$; HRMS $m / z$ calcd for $\mathrm{C}_{40} \mathrm{H}_{41} \mathrm{~N}_{4} \mathrm{O}_{6} \mathrm{P}_{2}[\mathrm{M}+\mathrm{H}]^{+} 735.3501$, found 735.3497 .

Cobalt[tetraethyl $\left(\left[2,2^{\prime}: 6^{\prime}, 2^{\prime \prime}: 6^{\prime \prime}, 2^{\prime \prime \prime}\right.\right.$-quaterpyridine] $-4^{\prime}, 4^{\prime \prime}$-diylbis $(4,1$ phenylene)) bis(phosphonate)] bis-chloro (Co-qPyE): $\mathrm{CoCl}_{2} \cdot 6 \mathrm{H}_{2} \mathrm{O}$ (75.5 mg, 0.31 $\mathrm{mmol})$ was dissolved in methanol $(6 \mathrm{~mL})$. A solution of compound $3(233 \mathrm{mg}, 0.31$ $\mathrm{mmol})$ in chloroform $(6 \mathrm{~mL})$ was added slowly with stirring at ambient temperature. A brown solid was formed gradually upon stirring, and the mixture was stirred for $2 \mathrm{~h}$. The solid was filtered and washed with methanol and chloroform to remove the unreacted ligand and $\mathrm{CoCl}_{2} \cdot 6 \mathrm{H}_{2} \mathrm{O}$. The solid was dried under vacuum to result in yellow powder. Yield: $120 \mathrm{mg}$ (45\%). Anal. Calcd. for $\mathrm{C}_{40} \mathrm{H}_{40} \mathrm{Cl}_{2} \mathrm{CoN}_{4} \mathrm{O}_{6} \mathrm{P}_{2}$ : C, 55.57; H, 4.66; N, 6.48. Found: C, 55.70; H, 4.76; N, 6.98; HRMS $m / z$ calcd for $\mathrm{C}_{40} \mathrm{H}_{40} \mathrm{CoN}_{4} \mathrm{O}_{6} \mathrm{P}_{2}\left[\mathrm{M}-2 \mathrm{Cl}^{-}\right]^{2+} 793.1755$, found 793.1762.

Cobalt $\left[2,2^{\prime}: 6^{\prime}, 2^{\prime \prime}: 6^{\prime \prime}, 2^{\prime \prime \prime}\right.$-quaterpyridine $]-4^{\prime}, 4^{\prime \prime}$-diylbis $(4,1$-phenylene $)$ bis

(phosphonic acido)]bis-chloro (Co-qPyH): hydrolysis of phosphonate ester groups of Co-qPyE could not be accomplished in refluxing at $6 \mathrm{~N} \mathrm{HCl}$ as usual owing to high risk of decomplexation, so the following procedure was instead followed. Co-qPyE (50 mg, $0.06 \mathrm{mmol}$ ) was taken in an oven-dried three-neck round-bottom flask kept under Ar atmosphere. About $6 \mathrm{~mL}$ of extra dry DMF was added followed by $0.25 \mathrm{~mL}$ of distilled triethylamine added to the mixture. Then $0.15 \mathrm{~mL}$ of $\mathrm{SiMe}_{3} \mathrm{Br}$ was added to the reaction mixture dropwise, and the reaction mixture was 

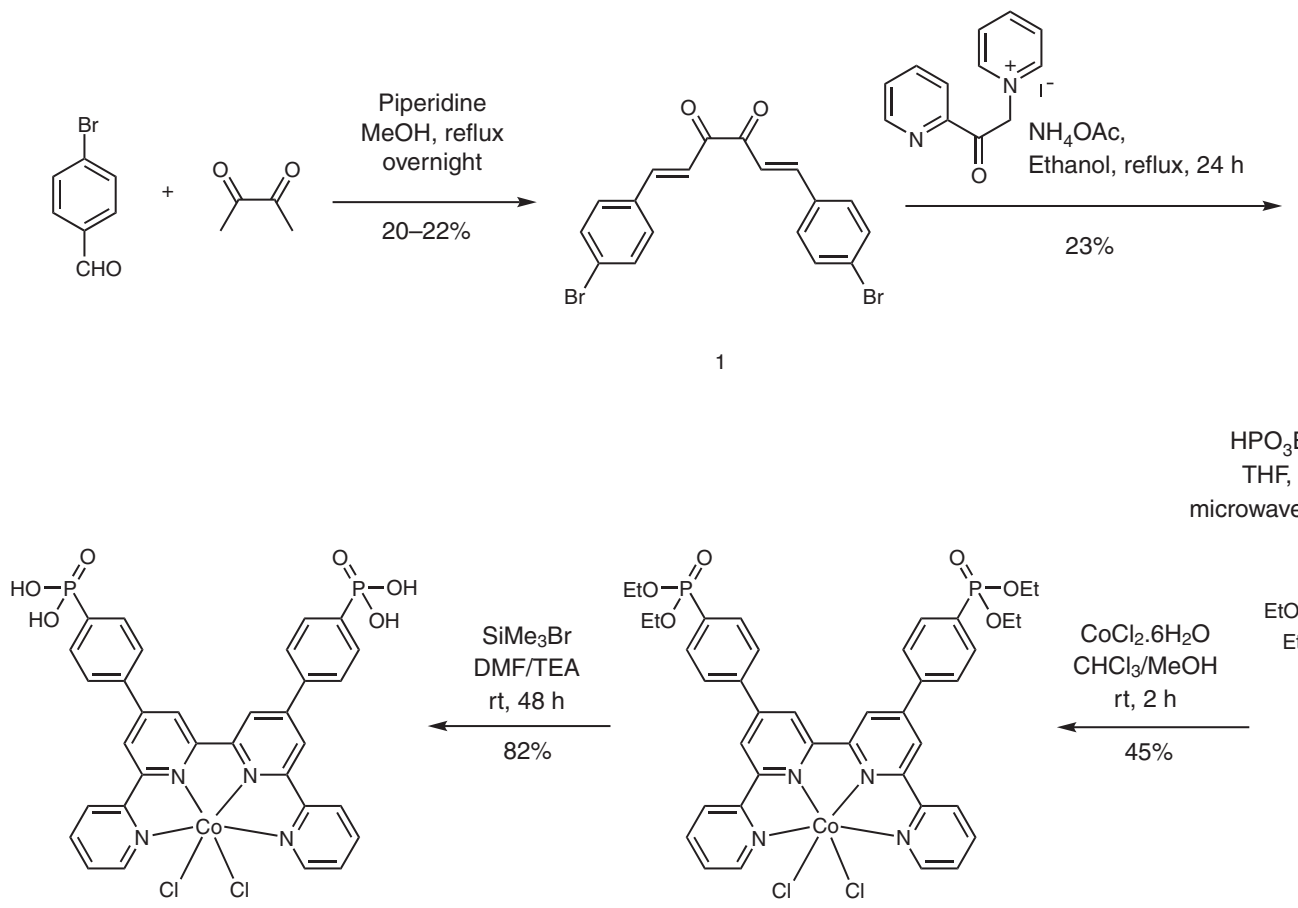

Co-qPyH

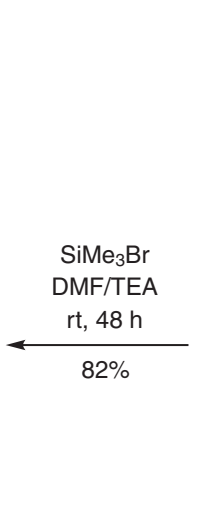

DMF/TEA

$\mathrm{rt}, 48 \mathrm{~h}$

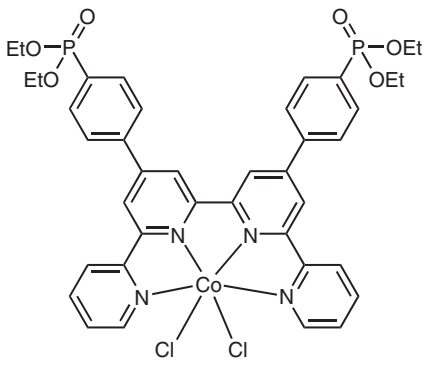

Co-qPyE

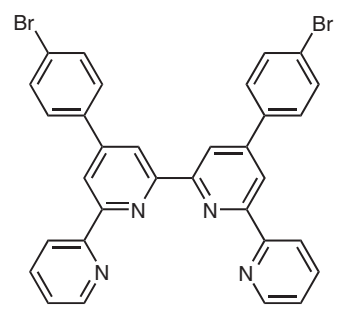

2

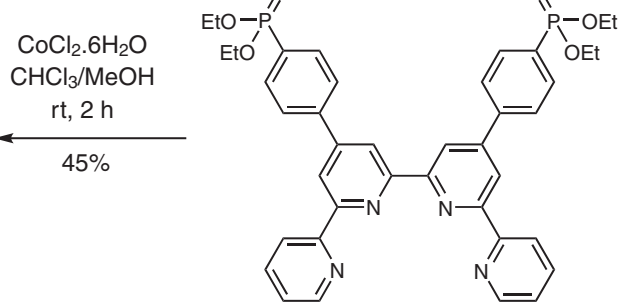

3

Fig. 7 Synthetic route for Co-qPyH. Successive synthetic steps along with chemical yields.

stirred for $48 \mathrm{~h}$ at $45^{\circ} \mathrm{C}$. The reaction mixture was cooled, and solvent was removed through reduced pressure. The residue was diluted with very dilute aqueous solution of $\mathrm{HCl}(\mathrm{pH}=6.8)$ to remove quaternary ammonium salt formed during reaction and protonation of phosphonic acid. The brown precipitate was filtered and washed with water and dried under vacuum to produce $36 \mathrm{mg}$ (yield $=82 \%$ ) of Co-qPyH. Anal. Calcd. for $\mathrm{C}_{32} \mathrm{H}_{24} \mathrm{Cl}_{2} \mathrm{CoN}_{4} \mathrm{O}_{6} \mathrm{P}_{2} \cdot 3.1 \mathrm{H}_{2} \mathrm{O}$ : C, 47.56; H, 3.77; N, 6.93. Found: C, 48.07; H, 4.23; N, 6.93. HRMS $m / z$ calcd for $\mathrm{C}_{32} \mathrm{H}_{24} \mathrm{CoN}_{4} \mathrm{O}_{6} \mathrm{P}_{2}$ $\left[\mathrm{M}-2 \mathrm{Cl}^{-}\right]^{2+} 681.0503$, found 681.0494 .

Nuclear magnetic resonance (NMR). ${ }^{1} \mathrm{H}$ and ${ }^{13} \mathrm{C}$ NMR spectra were recorded on an AVANCE 300 UltraShield BRUKER and AVANCE 400 BRUKER. Chemical shifts for ${ }^{1} \mathrm{H}$ and ${ }^{13} \mathrm{C}$ NMR spectra are referenced relative to residual protium and ${ }^{13} \mathrm{C}$ in the deuterated solvent $\left(\mathrm{CDCl}_{3} \delta=7.26 \mathrm{ppm}\right.$ for ${ }^{1} \mathrm{H}$ and $\delta=77.16 \mathrm{ppm}$ for ${ }^{13} \mathrm{C}$ ). NMR spectra were recorded at room temperature; chemical shifts are given in ppm and coupling constants in Hz. NMR spectra are available in Supplementary Figs. 10-12.

HRMS. High-resolution mass (HRMS) spectra were obtained by electrospray ionization coupled with high-resolution ion trap orbitrap (LTQ-Orbitrap, ThermoFisher Scientific) working in ion-positive or ion-negative mode.

Mesoporous $\mathrm{TiO}_{2}$ layer preparation. FTO-conductive glass substrates (F-doped $\mathrm{SnO}_{2}$ ) were purchased from Pilkington (TEC8). Three successive layers of $\mathrm{TiO}_{2}$ were then screen-printed using a transparent colloidal paste (Dyesol DSL 18NR-T) with 10-min-long drying steps at $100^{\circ} \mathrm{C}$ between each layer. Overall, the thickness of the film was ca. $12 \mu \mathrm{m}$. The obtained substrates were then sintered at $450^{\circ} \mathrm{C}$, following a progressive heating ramp $\left(325^{\circ} \mathrm{C}\right.$ for $5 \mathrm{~min}, 375^{\circ} \mathrm{C}$ for $5 \mathrm{~min}$, and $450^{\circ} \mathrm{C}$ for $\left.30 \mathrm{~min}\right)$.

Dense thin layer ( $-5-10-\mathrm{nm}$ thick) of $\mathrm{TiO}_{2}$ as protective film deposition. $\mathrm{TiO}_{2}$ was RF-sputtered from a ceramic target (3-in. diameter, purity $99.99 \%$ ) at room temperature. The base pressure in the deposition chamber was lower than $10^{-6}$ mbar before the sputerring gas (pure Ar) was introduced and the plasma created. Deposition duration was about 20 min with a power of $150 \mathrm{~W}$; these rather soft conditions were applied not to degrade the quality of the CIGS/CdS p-n junction through local heating or any other sputter damages.

Mott-Schottky measurement. The Mott-Schottky plot was obtained from IMPEImpedance-Potential measurements using a CHI 760 potentiostat with a m- $-\mathrm{TiO}_{2} \mid$ FTO electrode (three-electrode configuration). Potential range was $0.5-1.4 \mathrm{~V}$ vs. RHE in $1 \mathrm{M} \mathrm{KOH} \mathrm{(pH} \mathrm{13.9).} \mathrm{The} \mathrm{frequency} \mathrm{was} \mathrm{set} \mathrm{to} 1000 \mathrm{~Hz}$ and the amplitude to $0.01 \mathrm{~V}$. Epoxy resin was used to cover any exposed FTO, leaving only the $\mathrm{TiO}_{2}$ exposed. The donor density, $N_{D}$, was calculated from the slopes of the Mott-Schottky plot, using Eq. $(1)^{35}$

$$
\frac{1}{C^{2}}=\frac{2}{e \varepsilon \varepsilon_{0} N_{D}}\left(E-E_{f b}-\frac{k T}{e}\right)
$$

with a dielectric constant $(\varepsilon)$ of 75 for $\mathrm{TiO}_{2}{ }^{36}$.

Adsorption of Co-qPyH on $\mathbf{T i O}_{\mathbf{2}}$. A $0.2 \mathrm{mM}$ solution of $\mathbf{C o - q P y H}$ in $10 \mathrm{~mL}$ of methanol was prepared; then two drops of water were added, and the mixture was sonicated for $10 \mathrm{~min}$ with continuous degassing by Ar. Then electrodes were dipped into this solution, and this bath was heated at $45^{\circ} \mathrm{C}$ for $48 \mathrm{~h}$. The electrodes were carefully rinsed with methanol and dried under nitrogen atmosphere.

UV-vis. Ultraviolet-visible (UV-vis) absorption spectra were recorded with a Variant Cary 300 spectrometer, using $1-\mathrm{cm}$ path-length cells. $\mathrm{TiO}_{2}$ surface spectrum shows a slight bathochromic shift of the $\pi-\pi^{*}$ intragap transition upon grafting the cobalt quaterpyridine complex $\mathbf{C o - q P y H}$ (Supplementary Fig. 3) as already observed in the related case ${ }^{37}$.

ART-IR. ART-IR spectra were recorded on BRUKER Tensor 27.

Inductively coupled plasma. Cobalt catalyst was desorbed from the electrode with $69 \% \mathrm{HNO}_{3}$ solution. Solutions were then diluted to $1.38 \% \mathrm{HNO}_{3}$ and injected into ICP. ICAP 6300 Thermoelectron apparatus was used with detection of cobalt (238.8-nm band that is the most intense).

X-ray photoelectron spectrometer. X-ray photoelectron spectrometer analyses were performed with a THERMO-VG ESCALAB 250 (RX source K AI $(1486.6 \mathrm{eV}))$.

CIGS electrode preparation. $\mathrm{CuIn}_{0.1} \mathrm{Ga}_{0.9} \mathrm{Se}_{2}$ (CIGS) layers were grown onto Mocoated soda-lime glass substrates by co-evaporation from elemental sources. The soda-lime glass consists of 1 -mm-thick microscope slides $\left(1 \times 3\right.$ in. $\left.{ }^{2}\right)$. Mo back contact was deposited by DC sputtering, with total thickness of $500 \mathrm{~nm}$. The process used for CIGS deposition is known as CuPRO process (for more details see ref. ${ }^{38}$ ), which consists of keeping In and $\mathrm{Ga}$ fluxes constant and changing $\mathrm{Cu}$ flux such that nominal composition of the growing film undergoes $\mathrm{Cu}$-poor/Cu-rich transitions needed for high-performance devices ${ }^{39}$. Substrate temperature was kept constant $\left(580^{\circ} \mathrm{C}\right)$ during the whole deposition, and the thickness of the final films is about $2 \mu \mathrm{m}$. 
The n-type partner of the junction was a 40 -nm-thick CdS grown by chemical bath deposition. The p-CIGS/n-CdS heterojunction was finally covered with RFsputtered $\mathrm{ZnO} / \mathrm{ZnO}$ :Al bilayer. For the present study, since two device configurations were used (see below), the applied $\mathrm{ZnO}$ :Al-layer thickness was compromised and chosen at $300 \mathrm{~nm}\left(R_{\text {sheet }}=20 \Omega / \mathrm{sq}\right)$ although usually thinner for such wide-gap absorber-based solar cells. A scanning electron microscope crosssection image of the film is shown in Supplementary Fig. 6.

$J(V)$ curve measurement. $J(V)$ measurements were performed in conditions as close as possible to those defined by standard testing conditions, namely at $25^{\circ} \mathrm{C}$, under AM1.5 (using filtered light source) normalized at $1000 \mathrm{~W} \mathrm{~m}^{-2}$. The size of the investigated solar cells was about $1 \times 0.5 \mathrm{~cm}^{2}$. The actual value of $J_{\mathrm{sc}}$ was deduced from the integration of EQE measured from a laboratory-built setup. The surface shaded by the grids, accounted in the $J_{\mathrm{sc}}$ calculation, is about $3 \%$

EC measurements. EC and PEC experiments were performed using a $\mathrm{CHI} 760$ or a PGSTAT $302 \mathrm{~N}$ Autolab potentiostat-galvanostat. Electrolytes were saturated with the gas of interest by bubbling more than 20 min prior to measurement. A standard three-electrode EC setup was used. Counter electrode (CE) was a platinum grid, separated from the working compartment by a glass frit bridge filled with the same electrolyte. Potentials were measured relative to a saturated calomel electrode (SCE) as reference electrode (Ref) and converted into relative hydrogen electrode (RHE) using Eq. (2)

$$
E(\text { Vvs. RHE })=E(\text { Vvs.SCE })+0.242+0.059 \times \mathrm{pH} .
$$

For PV + EC, the external CIGS PV cell is connected in series with a Co-qPyH m- $\mathrm{TiO}_{2}$ electrode. Front $(-)$ and back $(+)$ lateral contacts of the cell were taken on $\mathrm{ZnO}: \mathrm{Al}$ and Mo layers, respectively. When the geometric surface of $\mathrm{TiO}_{2}$ is different from the surface of irradiated CIGS, current density is reported per surface of electrode and per surface of PV. When only one single value is reported for current density, it means that both CIGS and $\mathrm{TiO}_{2}$ surfaces have been intentionally set to the same value.

In PEC configuration, working electrode was covered with an insulating tape covering the edges to avoid contact between underlayers and electrolyte. A window was previously cut in this tape to define the working area. Working surface was between 0.15 and $0.25 \mathrm{~cm}^{2}$.

Irradiation was simulated with a $150-\mathrm{W}$ xenon lamp from Oriel Instrument with light source positioned at $20 \mathrm{~cm}$ from the PV cell for PV + EC configuration and $25 \mathrm{~cm}$ from the photoelectrode in PEC configuration. UV light was filtered at wavelength below $\lambda=435 \mathrm{~nm}$ with a low-pass filter. Part of the light above 1000 $\mathrm{nm}$ was also filtered via a water filter to avoid electrolyte warmup. In PEC configuration, the cell was equipped with a quartz window to avoid parasite light absorption.

Gas chromatography. GC analyses of gas evolved in the headspace during the electrolysis were performed with an Agilent Technologies 7820A GC system equipped with a thermal conductivity detector. Conditions allowed detection of $\mathrm{H}_{2}$, $\mathrm{O}_{2}, \mathrm{~N}_{2}, \mathrm{CO}$, and $\mathrm{CO}_{2}$. Calibration curves for $\mathrm{H}_{2}$ and $\mathrm{CO}$ were determined separately by injecting known volumes of pure gas. From product quantification, TON and TOF are calculated from Eqs. 3 and 4, respectively

$$
\begin{gathered}
\mathrm{TON}=n_{\text {product }} / n_{\text {catalyst,film }}, \\
\mathrm{TOF}=\mathrm{TON} / t,
\end{gathered}
$$

Because the electrolysis is not conducted until total deactivation of the catalyst, the given TON value can only be regarded as a lower estimation of the actual value. Also, it is important to recall that in many cases, the amount of electrochemically active molecular catalyst can be an order of magnitude smaller than the amount of catalyst present at the electrode ${ }^{22,40}$. It may also lead to an underestimated value of the calculated TON. Finally, because the amount of active catalyst in the film is decaying over time, the TOF value is an apparent, lowest estimation.

Chemicals. Chemicals were purchased from Sigma-Aldrich or Alfa Aesar and used as received. Thin-layer chromatography was performed on aluminum sheets precoated with Merck 5735 Kieselgel $60 \mathrm{~F}_{254}$. Column chromatography was carried out with Merck 5735 Kieselgel 60F (0.040-0.063-mm mesh). All gases were supplied by Air Liquide.

\section{Data availability}

Data supporting the findings of this study are available within the article and its Supplementary Information, or from the corresponding authors upon reasonable request.

Received: 22 March 2020; Accepted: 12 June 2020;

Published online: 13 July 2020

\section{References}

1. Coleman, A., Brennan, C., Vos, J. G. \& Pryce, M. T. Photophysical properties and applications of $\operatorname{Re}(\mathrm{I})$ and $\operatorname{Re}(\mathrm{I})-\mathrm{Ru}(\mathrm{II})$ carbonyl polypyridyl complexes. Coord. Chem. Rev. 252, 2585-2595 (2008).

2. Morris, A. J., Meyer, G. J. \& Fujita, E. Molecular approaches to the photocatalytic reduction of carbon dioxide for solar fuels. Acc. Chem. Res. 42, 1983-1994 (2009).

3. Sato, S., Arai, T. \& Morikawa, T. Toward solar-driven photocatalytic $\mathrm{CO}_{2}$ reduction using water as an electron donor. Inorg. Chem. 54, 5105-5113 (2015).

4. Kou, Y. et al. Visible light-induced reduction of carbon dioxide sensitized by a porphyrin-rhenium dyad metal complex on p-type semiconducting $\mathrm{NiO}$ as the reduction terminal end of an artificial photosynthetic system. J. Catal. 310, 57-66 (2014)

5. Sahara, G. et al. Photoelectrochemical reduction of $\mathrm{CO}_{2}$ coupled to water oxidation using a photocathode with a $\mathrm{Ru}(\mathrm{II})-\mathrm{Re}(\mathrm{I})$ complex photocatalyst and $\mathrm{CoO}_{\mathrm{x}} / \mathrm{TaON}$ photoanode. J. Am. Chem. Soc. 138, 14152-14158 (2016).

6. Li, T.-T., Shan, B. \& Meyer, T. J. Stable molecular photocathode for solardriven $\mathrm{CO}_{2}$ reduction in aqueous solutions. ACS Energy Lett. 4, 629-636 (2019).

7. Bradley, M. G., Tysak, T., Graves, D. J. \& Viachiopoulos, N. A. Electrocatalytic reduction of carbon dioxide at illuminated p-type silicon semiconducting electrodes. Chem. Commun. 349-350 (1983)

8. Beley, M., Collin, J.-P., Sauvage, J.-P., Petit, J.-P. \& Chartier, P. Photoassisted electro-reduction of $\mathrm{CO}_{2}$ on $\mathrm{p}-\mathrm{GaAs}$ in the presence of $\mathrm{Ni}$ cyclam ${ }^{2+} . J$. Electroanal. Chem. Interf. Electrochem. 206, 333-339 (1986).

9. Collin, J. P. \& Sauvage, J. P. Electrochemical reduction of carbon dioxide mediated by molecular catalysts. Coord. Chem. Rev. 93, 245-268 (1989).

10. Kumar, B., Smieja, J. M. \& Kubiak, C. P. Photoreduction of $\mathrm{CO}_{2}$ on p-type silicon using $\operatorname{Re}\left(\right.$ bipy-But) $(\mathrm{CO})_{3} \mathrm{Cl}$ : photovoltages exceeding $600 \mathrm{mV}$ for the selective reduction of $\mathrm{CO}_{2}$ to CO. J. Phys. Chem. C 114, 14220-14223 (2010).

11. Arai, T. et al. Photoelectrochemical reduction of $\mathrm{CO}_{2}$ in water under visiblelight irradiation by a p-type InP photocathode modified with an electropolymerized ruthenium complex. Chem. Commun. 46, 6944-6946 (2010).

12. Torralba-Peñalver, E., Luo, Y., Compain, J.-D., Chardon-Noblat, S. \& Fabre, B. Selective catalytic electroreduction of $\mathrm{CO}_{2}$ at silicon nanowires (SiNWs) photocathodes using non-noble metal-based manganese carbonyl bipyridyl molecular catalysts in solution and grafted onto SiNWs. ACS Catal. 5, 6138-6147 (2015).

13. $\mathrm{He}, \mathrm{D}$. et al. Photoelectrochemical $\mathrm{CO}_{2}$ reduction by a molecular cobalt(II) catalyst on planar and nanostructured Si. Surf. Chem. Eur. J. 22, 13064-13067 (2016).

14. Kumar, B. et al. Photochemical and photoelectrochemical reduction of $\mathrm{CO}_{2}$. Annu. Rev. Phys. Chem. 63, 541-CO569 (2012).

15. Sato, $\mathrm{S}$. et al. Selective $\mathrm{CO}_{2}$ conversion to formate conjugated with $\mathrm{H}_{2} \mathrm{O}$ oxidation utilizing semiconductor/complex hybrid photocatalysts. J. Am. Chem. Soc. 133, 15240-15243 (2011).

16. Schreier, M. et al. Efficient and selective carbon dioxide reduction on low cost protected $\mathrm{Cu}_{2} \mathrm{O}$ photocathodes using a molecular catalyst. Energy Environ. Sci. 8, 855-861 (2015).

17. Schreier, M. et al. Covalent immobilization of a molecular catalyst on $\mathrm{Cu}_{2} \mathrm{O}$ photocathodes for $\mathrm{CO}_{2}$ reduction. J. Am. Chem. Soc. 138, 1938-1946 (2016)

18. Sekizawa, K., Sato, S., Arai, T. \& Morikawa, T. Solar-driven photocatalytic $\mathrm{CO}_{2}$ reduction in water utilizing a ruthenium complex catalyst on p-Type $\mathrm{Fe}_{2} \mathrm{O}_{3}$ with a multiheterojunction. ACS Catal. 8, 1405-1416 (2018).

19. Shan, B. et al. Binary molecular-semiconductor $\mathrm{p}-\mathrm{n}$ junctions for photoelectrocatalytic $\mathrm{CO}_{2}$ reduction. Nat. Energy 4, 290-299 (2019).

20. Leung, J. J. et al. Solar-driven reduction of aqueous $\mathrm{CO}_{2}$ with a cobalt bis (terpyridine)-based photocathode. Nat. Catal. 2, 354-365 (2019).

21. Gerischer, H. On the stability of semiconductor electrodes against photodecomposition. J. Electroanal. Chem. Interf. Electrochem. 82, 133-143 (1977).

22. Wang, M., Chen, L., Lau, T.-C. \& Robert, M. A hybrid Co quaterpyridine complex/carbon nanotube catalytic material for $\mathrm{CO}_{2}$ reduction in water. Angew. Chem. Int. Ed. 57, 7769-7773 (2018).

23. Lam, K.-M., Wong, K.-Y., Yang, S.-M. \& Che, C.-M. Cobalt and nickel complexes of $2,2^{\prime}: 6^{\prime}, 2^{\prime \prime}: 6^{\prime \prime}, 2^{\prime \prime \prime}$-quaterpyridine as catalysts for electrochemical reduction of carbon dioxide. Dalton Trans. 1103-1107 (1995).

24. Guo, Z. et al. Highly efficient and selective photocatalytic $\mathrm{CO}_{2}$ reduction by iron and cobalt quaterpyridine complexes. J. Am. Chem. Soc. 138, 9413-9416 (2016).

25. Cometto, C. et al. Molecular electrochemical catalysis of the $\mathrm{CO}_{2}$-to- $\mathrm{CO}$ conversion with a Co complex: a cyclic voltammetry mechanistic investigation. Organometallics 38, 1280-1285 (2019).

26. Paniagua, S. A. et al. Phosphonic acids for interfacial engineering of transparent conductive oxides. Chem. Rev. 116, 7117-7158 (2016). 
27. Materna, K. L., Crabtree, R. H. \& Brudvig, G. W. Anchoring groups for photocatalytic water oxidation on metal oxide surfaces. Chem. Soc. Rev. 46 , 6099-6110 (2017).

28. Young, K. J. et al. Light-driven water oxidation for solar fuels. Coord. Chem. Rev. 256, 2503-2520 (2012).

29. Chen, Y., Feng, X., Liu, M., Su, J. \& Shen, S. Towards efficient solar-tohydrogen conversion: fundamentals and recent progress in copper-based chalcogenide photocathodes. Nanophotonics 5, 524-547 (2016).

30. Jacobsson, T. J., Fjällström, V., Edoff, M. \& Edvinsson, T. CIGS based devices for solar hydrogen production spanning from PEC-cells to PV-electrolyzers: a comparison of efficiency, stability and device topology. Sol. Energy Mater. Sol. Cells 134, 185-193 (2015).

31. Kobayashi, H. et al. Development of highly efficient $\mathrm{CuIn}_{0.5} \mathrm{Ga}_{0.5} \mathrm{Se}_{2}$-based photocathode and application to overall solar driven water splitting. Energy Environ. Sci. 11, 3003-3009 (2018).

32. Asaduzzaman, M., Hasan, M. \& Bahar, A. N. An investigation into the effects of band gap and doping concentration on $\mathrm{Cu}(\mathrm{In}, \mathrm{Ga}) \mathrm{Se}_{2}$ solar cell efficiency. SpringerPlus https://doi.org/10.1186/s40064-40016-42256-40068 (2016).

33. Nakamura, M. et al. Cd-free $\mathrm{Cu}(\mathrm{In}, \mathrm{Ga})(\mathrm{Se}, \mathrm{S})_{2}$ thin-film solar cell with record efficiency of 23.35\%. IEEE J. Photovolt. 9, 1863-1867 (2019).

34. Lebedev, D. et al. The Key $\mathrm{RuV}=\mathrm{O}$ intermediate of site-isolated mononuclear water oxidation catalyst detected by in situ X-ray absorption spectroscopy. J. Am. Chem. Soc. 140, 451-458 (2018).

35. Paracchino, A. et al. Ultrathin films on copper(I) oxide water splitting photocathodes: a study on performance and stability. Energy Environ. Sci. 5, 8673-8681 (2012).

36. King, D. M., Du, X., Cavanagh, A. S. \& Weimer, A. W. Quantum confinement in amorphous $\mathrm{TiO}_{2}$ films studied via atomic layer deposition. Nanotechnology 19, 445401 (2008).

37. Zhang, L. \& Cole, J. M. Dye aggregation in dye-sensitized solar cells. J. Mater. Chem. A 5, 19541-19559 (2017).

38. Kessler, J., Chityuttakan, C., Lu, J., Schöldström, J. \& Stolt, L. Cu(In,Ga)Se thin films grown with a Cu-poor/rich/poor sequence: growth model and structural considerations. Prog. Photovolt. Res. Appl. 11, 319-331 (2003).

39. Barreau, N., Painchaud, T., Couzinié-Devy, F., Arzel, L. \& Kessler, J. Recrystallization of CIGSe layers grown by three-step processes: a model based on grain boundary migration. Acta Mater. 58, 5572-5577 (2010).

40. Wang, $\mathrm{M}$. et al. $\mathrm{CO}_{2}$ electrochemical catalytic reduction with a highly active cobalt phthalocyanine. Nat. Commun. 10, 3602 (2019).

\section{Acknowledgements}

R.W. thanks the China Scholarship Council for her PhD fellowship (CSC student number 201806890019). The authors thank Philippe Decorse (Université de Paris) for the XPS measurements, Marie-Evelyne Pinart, and Gurvan Le Faucheur (Université de Paris) for ICP measurements. The authors are also grateful to Bruno Bresson from l'École supérieure de physique et de chimie industrielle de la ville de Paris (ESPCI) and Dorian
Joulié (Laboratoire d'Electrochimie Moléculaire, Université de Paris) for the EDX measurements and to Guillaume Thoraval (Universite de Paris) for the realization of an electrolysis cell equipped with a quartz window. Partial financial support from the French National Agency for Research (ANR-16-CE05-0010-01), from the Institut Universitaire de France (IUF), and from Région des Pays de la Loire (project "Hybrid Z-scheme," program LUMOMAT) is also gratefully acknowledged.

\section{Author contributions}

F.O. and M.R. designed and supervised the project. P.B.P. synthesized and characterized the catalysts. S.D., S.J., and N.B. prepared and characterized all the CIGS materials. R.W., E.B., and P.B.P. carried out the $\mathrm{CO}_{2}$ reduction experiments. R.W. and E.B. analyzed the XPS and EDX experiments. R.W., E.B., P.B.P., F.O., and M.R. analyzed the data. All authors discussed the results and assisted during paper preparation.

\section{Competing interests}

The authors declare no competing interests.

\section{Additional information}

Supplementary information is available for this paper at https://doi.org/10.1038/s41467 020-17125-4.

Correspondence and requests for materials should be addressed to N.B., F.O. or M.R.

Peer review information Nature Communications thanks the anonymous reviewers for their contribution to the peer review of this work. Peer reviewer reports are available.

Reprints and permission information is available at http://www.nature.com/reprints

Publisher's note Springer Nature remains neutral with regard to jurisdictional claims in published maps and institutional affiliations.

Open Access This article is licensed under a Creative Commons Attribution 4.0 International License, which permits use, sharing, adaptation, distribution and reproduction in any medium or format, as long as you give appropriate credit to the original author(s) and the source, provide a link to the Creative Commons license, and indicate if changes were made. The images or other third party material in this article are included in the article's Creative Commons license, unless indicated otherwise in a credit line to the material. If material is not included in the article's Creative Commons license and your intended use is not permitted by statutory regulation or exceeds the permitted use, you will need to obtain permission directly from the copyright holder. To view a copy of this license, visit http://creativecommons.org/ licenses/by/4.0/.

(C) The Author(s) 2020 